\title{
Intriguing Role of a Quaternary Ammonium Cation in the Dissociation Chemistry of Keggin Polyoxometalate Anions
}

\author{
Jie Cao, ${ }^{1}$ Chenchen $\mathrm{Li}^{2}{ }^{2}$ Zhengxiang Zhang, ${ }^{2}$ Chong Xu, ${ }^{1}$ Jie Yan, ${ }^{1}$ Fengyun Cui, ${ }^{1}$ \\ Changwen $\mathrm{Hu}^{1}$
}

${ }^{1}$ Key Laboratory of Cluster Science, Ministry of Education of China, School of Chemistry, Beijing Institute of Technology, Beijing, 100081, People's Republic of China

${ }^{2}$ Agilent Technologies Co., Ltd., Beijing, People's Republic of China

\begin{abstract}
The gas-phase fragmentations of a series of Keggin polyoxometalate anions with molecular formula of $\mathrm{TBA}_{n}\left[\mathrm{XM}_{12} \mathrm{O}_{40}\right](\mathrm{X}=\mathrm{P}, \mathrm{Si} ; \mathrm{M}=\mathrm{Mo}, \mathrm{W})$ were studied by electrospray ionization tandem mass spectrometry. The bare polyoxoanions $\left[\mathrm{XM}_{12} \mathrm{O}_{40}\right]^{\text {n- }}$ as well as the non-covalent complexes $\left\{\mathrm{TBA}\left[\mathrm{XM}_{12} \mathrm{O}_{40}\right]\right\}^{(\mathrm{n}-1)-}$ and $\left\{\mathrm{TBA}_{\mathrm{m}}\left[\mathrm{XM}_{12} \mathrm{O}_{40}\right]_{2}\right\}^{3-}$ displayed characteristic dissociation pathways. Fragmentation of $\left[\mathrm{XM}_{12} \mathrm{O}_{40}\right]^{\text {n- }}$ led to pairs of complementary product anions whose total stoichiometry and charge matched those of the precursor anion, consistent with the previous study by $\mathrm{Ma}$ et al. The nature of the non-covalent interaction between $\left[\mathrm{XM}_{12} \mathrm{O}_{40}\right]^{\mathrm{n}-}$ and $\mathrm{TBA}^{+}$was addressed in detail via the example of $\left\{\mathrm{TBA}\left[\mathrm{XM}_{12} \mathrm{O}_{40}\right]\right\}^{(\mathrm{n}-1)-}$. The non-covalent interaction [1] primarily dominated by the Coulombic attraction of the opposite charges completely changed the dissociation chemistry of $\left[\mathrm{XM}_{12} \mathrm{O}_{40}\right]^{\mathrm{n}-}$. The non-covalent complexes $\left\{\mathrm{TBA}\left[\mathrm{XM}_{12} \mathrm{O}_{40}\right]\right\}^{(\mathrm{n}-1)-}$ and $\left\{\mathrm{TBA}_{\mathrm{m}}\left[\mathrm{XM}_{12} \mathrm{O}_{40}\right]_{2}\right\}^{3-}$, formed by the charge reduction during the electrospray process, underwent distinct dissociation routes: $\left\{\mathrm{TBA}\left[\mathrm{XM}_{12} \mathrm{O}_{40}\right]\right\}^{(\mathrm{n}-1)-}$ fragmented to give rise to its product ion $\left\{\left(\mathrm{C}_{4} \mathrm{H}_{9}\right)\left[\mathrm{XM}_{12} \mathrm{O}_{40}\right]\right\}^{(\mathrm{n}-1)-}$ by cleaving the $\mathrm{N}-\mathrm{C}$ covalent bond inside the $\mathrm{TBA}^{+}$cation whereas $\left\{\mathrm{TBA}_{\mathrm{m}}\left[\mathrm{XM}_{12} \mathrm{O}_{40}\right]_{2}\right\}^{3-}$ dissociated into a pair of product ions, $\left\{\mathrm{TBA}_{\mathrm{i}}\left[\mathrm{XM}_{12} \mathrm{O}_{40}\right]\right\}^{2-}$ and $\left\{\mathrm{TBA}_{\mathrm{m}-\mathrm{i}}\left[\mathrm{XM}_{12} \mathrm{O}_{40}\right]\right\}$, by breaking the non-covalent bond between $\left[\mathrm{XM}_{12} \mathrm{O}_{40}\right]^{\mathrm{n}-}$ and TBA ${ }^{+}$. In addition, energy-variable CID was used to map the relative stabilities of the ion clusters in the gas phase, which was in excellent agreement with the relative orders of thermal stability in the condensed phase.
\end{abstract}

Key words: Keggin POM clusters, Non-covalent complex, Electrospray ionization tandem mass spectrometry, Gas-phase fragmentation, Tetrabutylammonium(TBA)

\section{Introduction}

$\mathrm{P}$ olyoxometalates (POMs) are a vast class of polynuclear molecular oxide anions usually formed by W, Mo, or $\mathrm{V}$. The well-known Keggin $\left[\mathrm{XM}_{12} \mathrm{O}_{40}\right]^{\mathrm{n}-}$ cluster (where $\mathrm{X}$ is the heteroatom and $\mathrm{M}$ is the addenda atom) represents one of the six classical POM structures with fascinating applica-

Correspondence to: Jie Cao; e-mail: jcao@bit.edu.cn, Changwen Hu; e-mail: cwhu@bit.edu.cn tions in catalysis. The Keggin structure is based on a central $\mathrm{XO}_{4}$ tetrahedron surrounded by $12 \mathrm{MO}_{6}$ octahedra arranged in four groups of three edge-shared octahedra, $\mathrm{M}_{3} \mathrm{O}_{13}$. These groups are linked by shared corners to each other and to the central $\mathrm{XO}_{4}$ tetrahedron [2].

Mass spectrometry (MS) has become an established analytical approach for POM clusters. The study of POM system by MS can be dated back to the 1980s [3]. Fast atom bombardment (FAB) was then used to examine a range of species [4-7]. The use of comparatively hard ionization techniques and resolution problems given by the unresolved 
isotope patterns of Mo- and W-containing clusters hampered MS from wide applications for complex problems in POM chemistry.

The advent of electrospray ionization mass spectrometry (ESI-MS) has transformed the analysis of complex inorganic ions [8]. It has been utilized recently to analyze a range of POM clusters in various complex systems [9-19], which includes identification of cluster speciation and unambiguous determination of the cluster composition in solution. The POM candidates well characterized so far by ESIMS range from small clusters to large cluster complexes; for instance, the largest polyoxometalate cluster complex of $\left[\mathrm{H}_{34} \mathrm{~W}_{119} \mathrm{Se}_{8} \mathrm{Fe}_{2} \mathrm{O}_{420}\right]^{54-}(>30 \mathrm{kDa}$ for the monomer and $>60 \mathrm{kDa}$ for the dimer) to be observed intact in solution by ESI-MS [19]. The overwhelming advantages of MS over X-ray crystallography and NMR are to provide key insights into the molar mass and stoichiometry of species in solution and to characterize transient intermediates relevant to the assembly of larger clusters.

Although a few systematic studies of the gas-phase fragmentation of POM clusters have been reported so far [12, 20-22], little attention has been paid to the interaction between the cations and the POM anions in the gas phase, which reflects intrinsic nature of interaction between these two entities. The interaction is simple in the case of alkali metal cations (i.e., $\mathrm{Na}$ ${ }^{+}, \mathrm{K}^{+}$, etc). However, it might involve multiple intermolecular interactions when cations are polyatomic species such as organic cations. How these cations interact with the POM anions in the gas phase and, therefore, participate in the dissociation chemistry of POM clusters in the gas phase remains unresearched. This kind of study relates to a special class of compounds: POM-based supramolecular assembles. This study allows us to better understanding the important role of cations on the formation of the POM anionic frameworks as structure directing agents [23-25] and on the control of catalytic activity of POM clusters [26-28].

The present work investigates the collision-induced dissociation (CID) fragmentation reactions of a series of cluster anions derived from ESI-MS spectra of the TBA $^{+}\left(=\left(n-\mathrm{C}_{4} \mathrm{H}_{9}\right)_{4} \mathrm{~N}^{+}\right)$salts of Keggin $\left[\mathrm{XM}_{12} \mathrm{O}_{40}\right]^{\mathrm{n}-}$ polyoxoanions ( $\mathrm{X}=\mathrm{P}, \mathrm{Si} ; \mathrm{M}=\mathrm{Mo}, \mathrm{W}$ ) with special focusing on the noncovalent interaction between the tetrabutylammonium cation and the polyoxoanion. The objective of this study is to unravel the intriguing role of the quaternary ammonium cations, a representative organic cation to form supramolecule with POM, in the dissociation chemistry of POM clusters in the gas phase.

The general strategy in the study includes assignment of the ion structure, elucidation of the ion dissociation mechanism, and determination of the relative ion stability in the gas phase.

\section{Experimental}

$\mathrm{TBA}_{\mathrm{n}}\left[\mathrm{XM}_{12} \mathrm{O}_{40}\right]$. All TBA salts of $\left[\mathrm{XM}_{12} \mathrm{O}_{40}\right]^{\mathrm{n}-}$ were synthesized according to the following cation-exchange process by using the respective free acids. Tetrabutylammo- nium bromide aqueous solution was added to $\mathrm{H}_{\mathrm{n}}\left[\mathrm{XM}_{12} \mathrm{O}_{40}\right]$ aqueous solution with stirring. The resultant precipitate was filtered and washed with water, ethanol, and ether, and dried under reduced pressure. Recrystallization from acetonitrile afforded the pure product.

\section{Mass Spectrometry}

Mass spectra were recorded on an Agilent 6520 Q-TOF LC/ MS mass spectrometer. The $\mathrm{m} / \mathrm{z}$ values refer to the highest peak of the clusters. All experiments were performed in negative mode by direct injection. The dual-spray electrospray ionization source condition was as follows: drying gas flow, $10 \mathrm{~L} / \mathrm{min}$; nebulizer, $38 \mathrm{psi}$; drying gas temperature, $350{ }^{\circ} \mathrm{C}$; Vcap, $3500 \mathrm{~V}$; scan range, $100-3000 \mathrm{~m} / \mathrm{z}$; fragmentator, $100 \mathrm{~V}$. Sample solutions were made to approximately $10^{-6} \mathrm{M}$ in acetonitrile and transferred to the electrospray source via an autosampler with a flow rate of $0.3 \mathrm{~mL} / \mathrm{min}$. CID experiments were performed using $\mathrm{N}_{2}$ as the target gas. The desired multiply-charged cluster was isolated and subjected to energy-variable collisional activated dissociation in which the applied collision energy was raised incrementally. Ten scans were averaged for each spectrum. Plots of relative abundance of the parent ion versus applied collisional energy were generated with Microcal Origin 5.0 (Microcal Software, Inc., Northampton, MA, USA) to determine $\mathrm{E}_{1 / 2}$ values. The dissociation curves were determined in triplicate for each cluster.

Tungsten- and molybdenum-containing ions display distinctive isotope patterns due to the relative abundances of the naturally occurring isotopes of each element. This allows the charge of ions to be assigned on the basis of peak separation and facilitates the assignment of ion stoichiometry via comparison of experimental and theoretical isotopomer patterns. All data were collected and processed using MassHunter workstation software.

\section{Results and Discussion}

\section{ESI Mass Spectra of $\mathrm{TBA}_{n}\left[\mathrm{XM}_{12} \mathrm{O}_{40}\right]$}

The negative-ion ESI mass spectra of $\mathrm{TBA}_{n}\left[\mathrm{XM}_{12} \mathrm{O}_{40}\right]$ in acetonitrile were presented in Figure 1. Well-defined mass spectra were given with limited speciation related to the bare Keggin polyoxoanions $\left[\mathrm{XM}_{12} \mathrm{O}_{40}\right]^{\mathrm{n}-}$ and the non-covalent complexes $\left\{\mathrm{TBA}\left[\mathrm{XM}_{12} \mathrm{O}_{40}\right]\right\}^{(\mathrm{n}-1)-}$ and $\left\{\mathrm{TBA}_{\mathrm{m}}\left[\mathrm{XM}_{12} \mathrm{O}_{40}\right]_{2}\right\}^{3-}$ in solution. Charge state distributions were from n- to 1and protonated species was absent for all cases.

It can be seen that the dominant species in all spectra was $\left[\mathrm{XM}_{12} \mathrm{O}_{40}\right]^{\mathrm{n}-}$ except for $\mathrm{TBA}_{4}\left[\mathrm{SiMo}_{12} \mathrm{O}_{40}\right]$. Moreover, the relative intensity of $\left[\mathrm{XM}_{12} \mathrm{O}_{40}\right]^{\mathrm{n}-}$ to $\left\{\mathrm{TBA}\left[\mathrm{XM}_{12} \mathrm{O}_{40}\right]\right\}^{(\mathrm{n}-1)-}$ was dependant on the solvent ratio of acetonitrile versus water. $\left[\mathrm{XM}_{12} \mathrm{O}_{40}\right]^{\mathrm{n}-}$ was favored over $\left\{\mathrm{TBA}\left[\mathrm{XM}_{12} \mathrm{O}_{40}\right]\right\}^{(\mathrm{n}-1)-}$ in pure acetonitrile whereas the order was reversed in 50:50 acetonitrile/water due to the well-known stabilisation of cations by acetonitrile [29]. The solution equilibrium (Equation 1) 

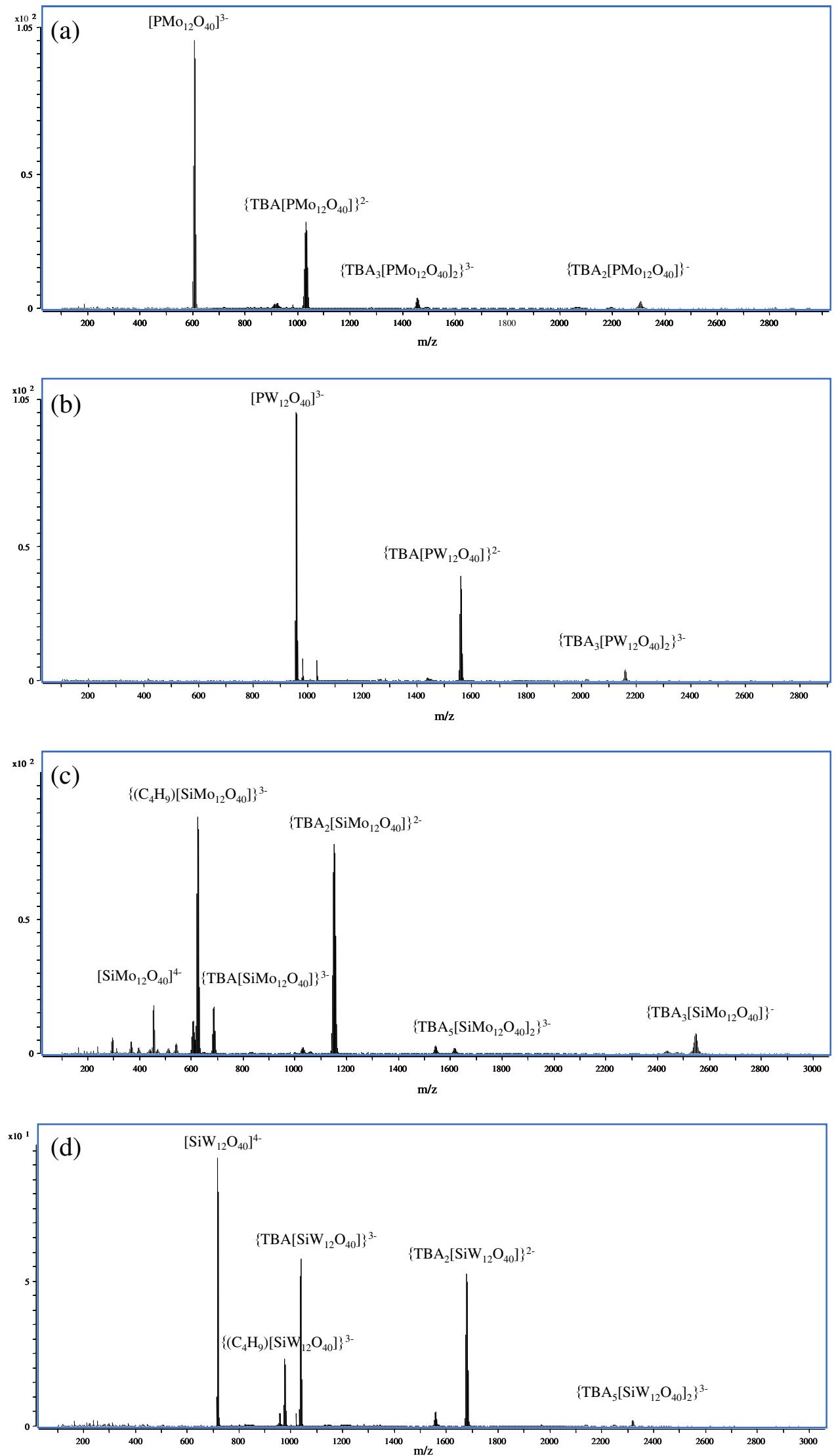

Figure 1. Negative-ion ESI mass spectra of (a) $(\mathrm{TBA})_{3}\left[\mathrm{PMo}_{12} \mathrm{O}_{40}\right]$, (b) $(\mathrm{TBA})_{3}\left[\mathrm{PW} \mathrm{W}_{12} \mathrm{O}_{40}\right]$, (c) $(\mathrm{TBA})_{4}\left[\mathrm{SiMo}_{12} \mathrm{O}_{40}\right]$, and (d) $(\mathrm{TBA})_{4}\left[\mathrm{SiW}_{12} \mathrm{O}_{40}\right]$ in $\mathrm{CH}_{3} \mathrm{CN}$ 

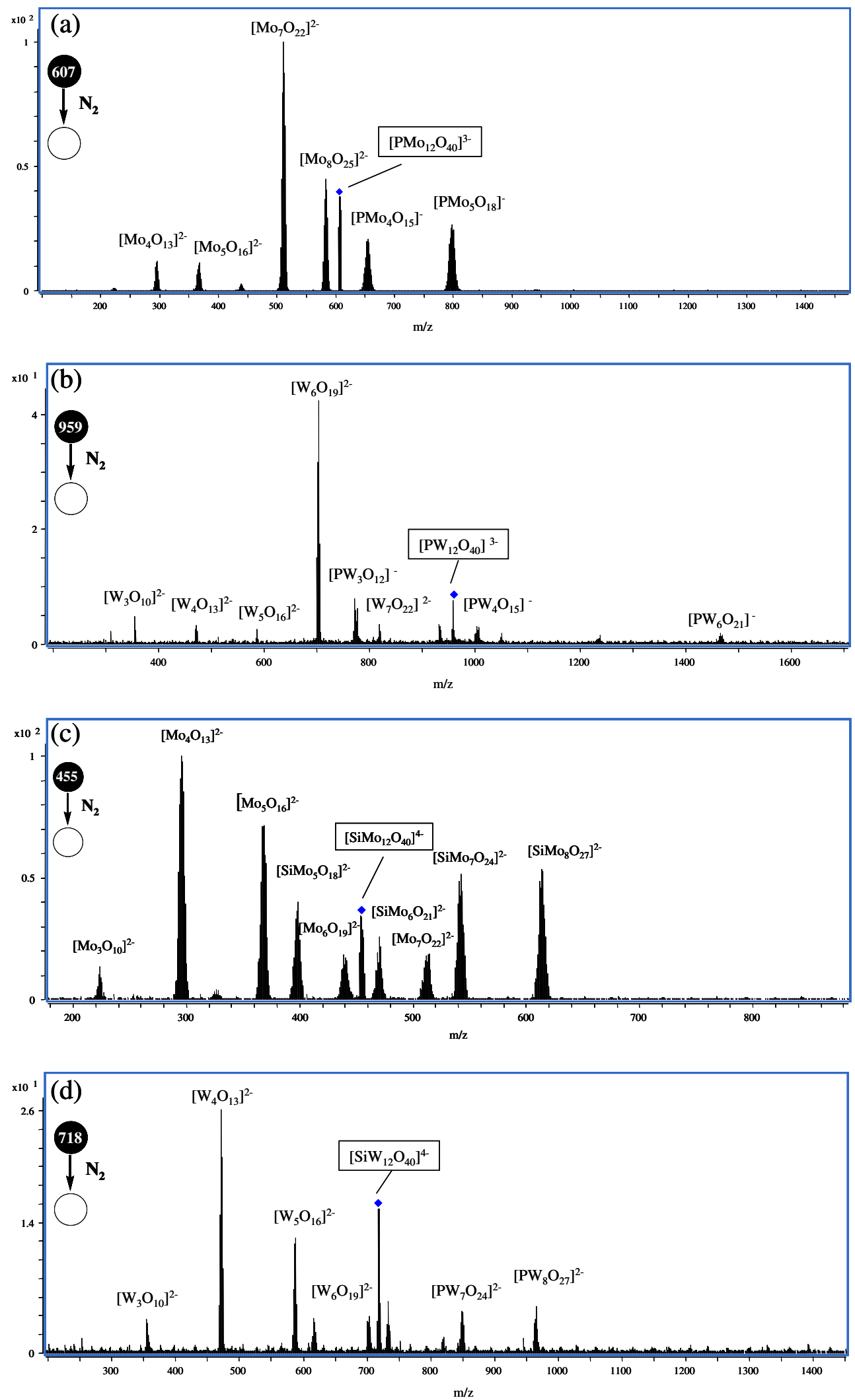

Figure 2. $\mathrm{CID}$ mass spectra of (a) $\left[\mathrm{PMo}_{12} \mathrm{O}_{40}\right]^{3-}$, (b) $\left[\mathrm{PW}_{12} \mathrm{O}_{40}\right]^{3-}$, (c) $\left[\mathrm{SiMo}_{12} \mathrm{O}_{40}\right]^{4-}$, and (d) $\left[\mathrm{SiW}_{12} \mathrm{O}_{40}\right]^{4-}$. The parent ion (denoted by a diamond) is shown in a square box in each spectrum 

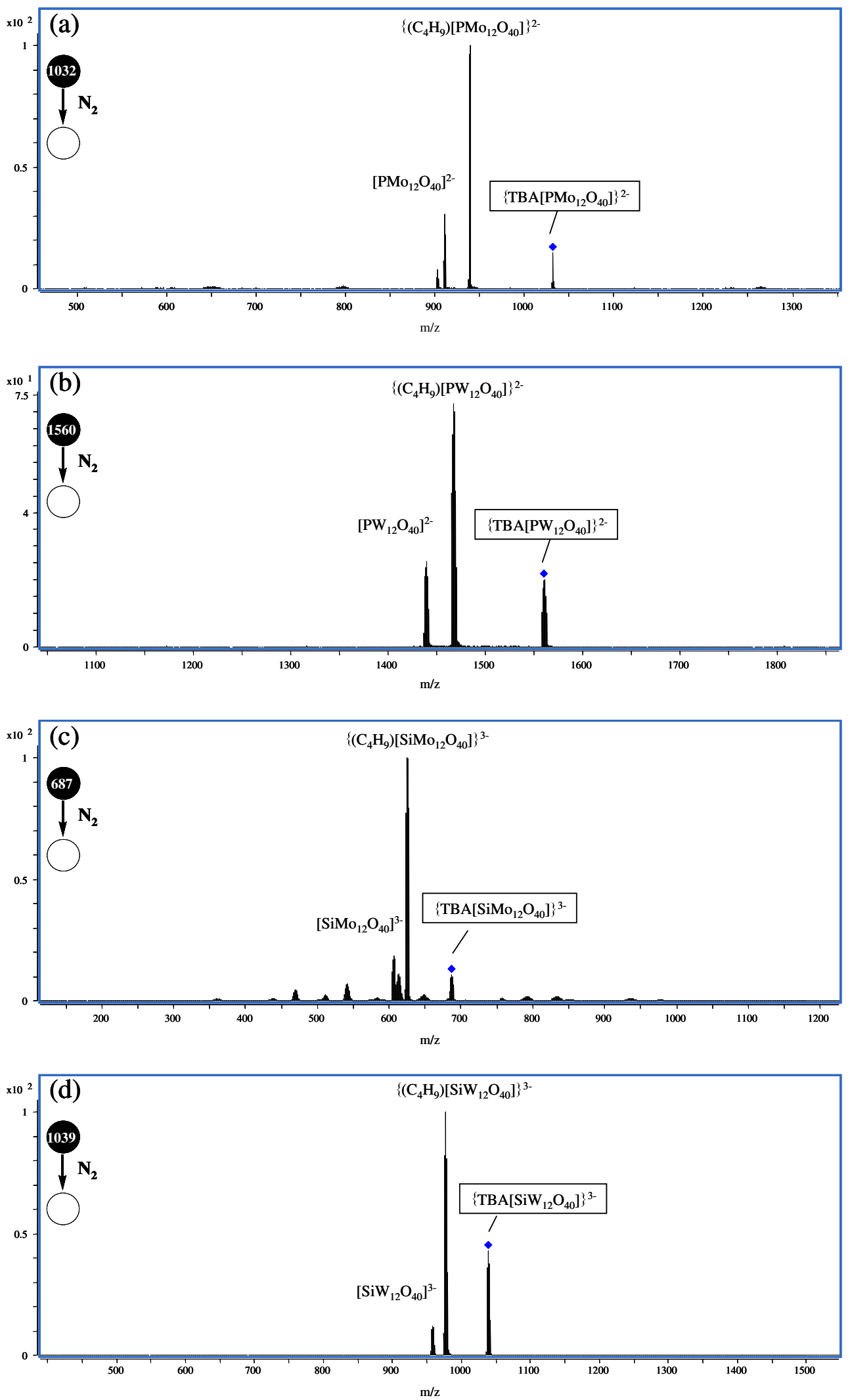

Figure 3. CID mass spectra of (a) $\left\{\mathrm{TBA}\left[\mathrm{PMO}_{12} \mathrm{O}_{40}\right]\right\}^{2-}$, (b) $\left\{\mathrm{TBA}\left[\mathrm{PW}_{12} \mathrm{O}_{40}\right]\right\}^{2-}$, (c) $\left\{\mathrm{TBA}\left[\mathrm{SiMO}_{12} \mathrm{O}_{40}\right]\right\}^{3-}$, and (d) $\left\{\mathrm{TBA}\left[\mathrm{SiW}_{12} \mathrm{O}_{40}\right]\right\}^{3-}$. The parent ion (denoted by a diamond) is shown in a square box in each spectrum 


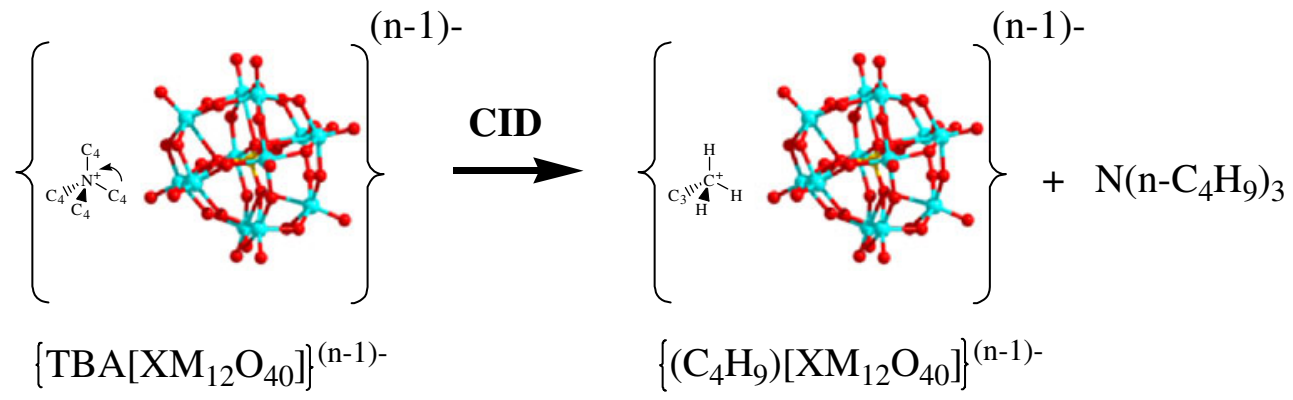

Figure 4. Fragmentation mechanism of the non-covalent complex $\left\{\mathrm{TBA}\left[\mathrm{XM}_{12} \mathrm{O}_{40}\right]\right\}^{(\mathrm{n}-1)-}$, in which the product ion $\left\{\left(\mathrm{n}-\mathrm{C}_{4} \mathrm{H}_{9}\right)\left[\mathrm{XM}_{12} \mathrm{O}_{40}\right]\right\}^{(\mathrm{n}-1)-}$ was generated
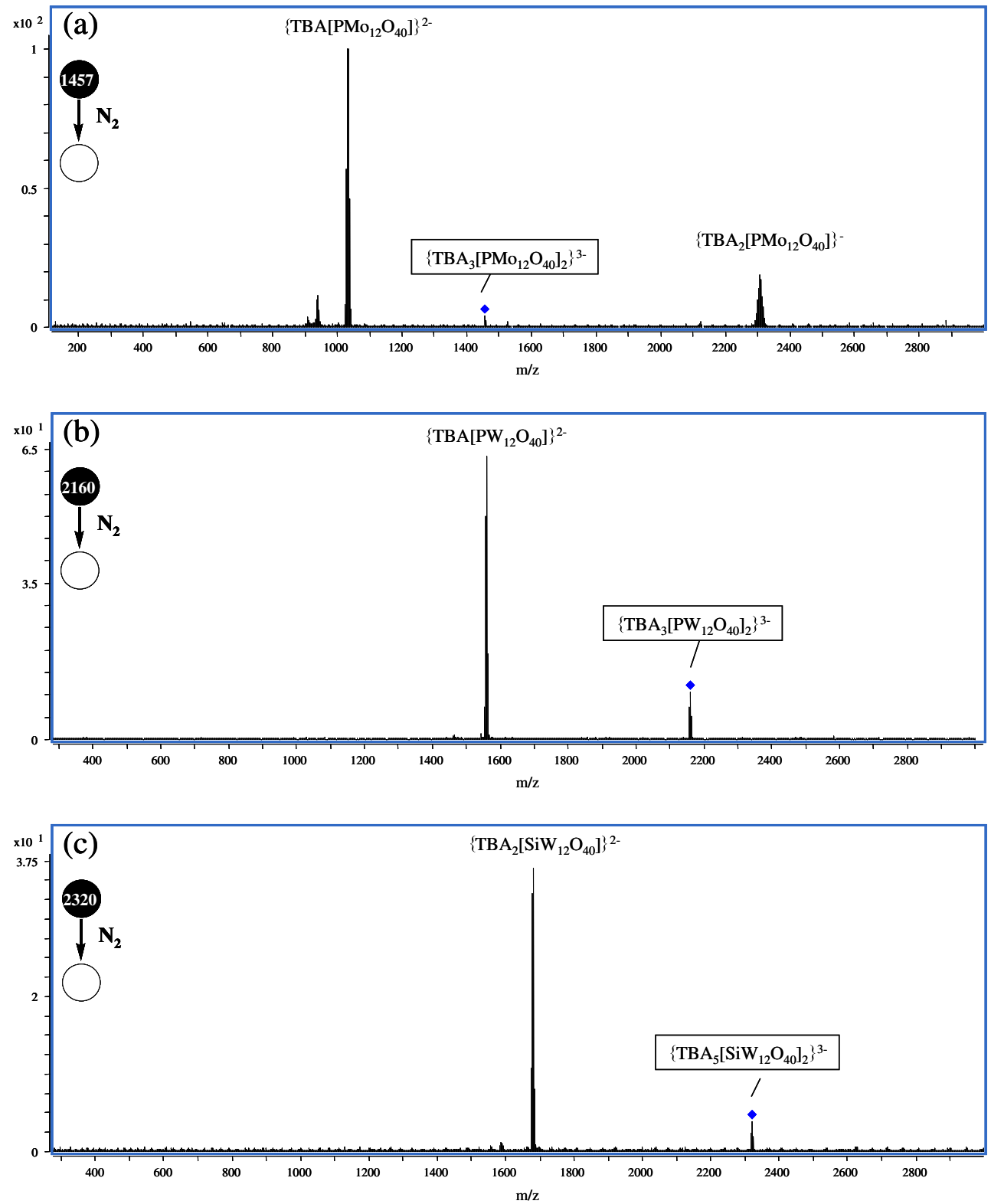

Figure 5. CID mass spectra of (a) $\left\{\mathrm{TBA}_{3}\left[\mathrm{PMO}_{12} \mathrm{O}_{40}\right]_{2}\right\}^{3-}$, (b) $\left\{\mathrm{TBA}_{3}\left[\mathrm{PW}_{12} \mathrm{O}_{40}\right]_{2}\right\}^{3-}$, (c) $\left\{\mathrm{TBA}_{5}\left[\mathrm{SiMo}_{12} \mathrm{O}_{40}\right]_{2}\right\}^{3-}$. The parent ion (denoted by a diamond) is shown in a square box in each spectrum 
associated with the $\left[\mathrm{XM}_{12} \mathrm{O}_{40}\right]^{\mathrm{n}-}$ and $\left\{\mathrm{TBA}\left[\mathrm{XM}_{12} \mathrm{O}_{40}\right]\right\}^{(\mathrm{n}-1)-}$ clusters was affected by the nature of solvent. In the case of acetonitrile, the equilibrium shifted to the right: more $\left\{\mathrm{TBA}\left[\mathrm{XM}_{12} \mathrm{O}_{40}\right]\right\}^{(\mathrm{n}-1)-}$ ions were converted into $\left[\mathrm{XM}_{12} \mathrm{O}_{40}\right]^{\mathrm{n}-}$ as a result of stronger ion-dipole interaction between acetonitrile and $\mathrm{TBA}^{+}$(the dipole moments of $\mathrm{CH}_{3} \mathrm{CN}$ and $\mathrm{H}_{2} \mathrm{O}$ are $3.92 \mathrm{D}$ and $1.85 \mathrm{D}$, respectively).

$$
\left\{\mathrm{TBA}\left[\mathrm{XM}_{12} \mathrm{O}_{40}\right]\right]^{(\mathrm{n}-1)-} \underset{50: 50 \mathrm{CH}_{3} \mathrm{CN} / \mathrm{H}_{2} \mathrm{O}}{\stackrel{\mathrm{CH}_{3} \mathrm{CN}}{\rightleftharpoons}}\left[\mathrm{XM}_{12} \mathrm{O}_{40}\right]^{\mathrm{n}-}+\mathrm{TBA}^{+}
$$

\section{Fragmentation of $\left[\mathrm{XM}_{12} \mathrm{O}_{40}\right]^{n-}$}

A common feature for the fragmentation of $\left[\mathrm{XM}_{12} \mathrm{O}_{40}\right]^{\mathrm{n}-}$ clusters is to yield pairs of complementary product anions, each pair comprising a dianionic isopolyoxometalate $\left[\mathrm{M}_{\mathrm{x}} \mathrm{O}_{3 \mathrm{x}+1}\right]^{2-}$ and a monoanionic or dianionic heteropolyoxometalate $\left[\mathrm{XM}_{12-\mathrm{x}} \mathrm{O}_{39-3 \mathrm{x}}\right]^{(\mathrm{n}-2)-}$ (Equation 2, Figure 2), as defined by $\mathrm{Ma}$ et al [21]. The total stoichiometry and charge of each pair of complementary product ions match those of the precursor anion. For example, $\left[\mathrm{PMo}_{12} \mathrm{O}_{40}\right]^{3-}$ fragmented to give pairs of product ions consisting of a dianionic isopolyoxomolybdate $\left[\mathrm{Mo}_{\mathrm{x}} \mathrm{O}_{3 x+1}\right]^{2-}$, and a monoanionic phospho-polyoxomolybdate $\left[\mathrm{PMo}_{12-\mathrm{x}} \mathrm{O}_{39-3 \mathrm{x}}\right]^{-}$, with the most intense pair being $\left[\mathrm{Mo}_{7} \mathrm{O}_{22}\right]^{2-}$ and $\left[\mathrm{PMo}_{5} \mathrm{O}_{18}\right]^{-}$. They account for the total charge and stoichiometry of $\left[\mathrm{PMo}_{12} \mathrm{O}_{40}\right]^{3-}$. This charge separation reaction is presumably driven by the instability of highly charged clusters due to the Coulombic repulsion in the bare clusters.

$\left[X M_{12} O_{40}\right]^{n-} \rightarrow\left[\mathrm{M}_{\mathrm{x}} \mathrm{O}_{3 \mathrm{x}+1}\right]^{2-}+\left[\mathrm{XM}_{12-\mathrm{x}} \mathrm{O}_{39-3 \mathrm{x}}\right]^{(\mathrm{n}-2)-}(\mathrm{X} \geq 3)$

\section{Dissociation Characteristics of Non-covalent Complexes $\left\{\mathrm{TBA}\left[\mathrm{XM}_{12} \mathrm{O}_{40}\right]\right\}^{(\mathrm{n}-1)-}$ and $\left\{\mathrm{TBA}_{m}\left[\mathrm{XM}_{12} \mathrm{O}_{40}\right]_{2}\right\}^{3-}$}

The mono $\mathrm{TBA}^{+}$-bound species, $\left\{\mathrm{TBA}\left[\mathrm{XM}_{12} \mathrm{O}_{40}\right]\right\}^{(\mathrm{n}-1)-}$, displays an interesting fragmentation pathway to generate a $\left\{\left(\mathrm{C}_{4} \mathrm{H}_{9}\right)\left[\mathrm{XM}_{12} \mathrm{O}_{40}\right]\right\}^{(\mathrm{n}-1)-}$ product ion plus a tertiary amine (Equation 3, Figure 3).

$\left\{N\left(C_{4} H_{9}\right)_{4}\left[X M_{12} O_{40}\right]\right\}^{(n-1)-} \rightarrow\left\{\left(C_{4} H_{9}\right)\left[X M_{12} O_{40}\right]\right\}^{(n-1)-}+N\left(C_{4} H_{9}\right)_{3}$

This result is notable, as it evidences the strong interaction between the organic ammonium cation and the polyoxometalate anion in the gas phase. The non-covalent interaction between the organic ammonium cation and the polyoxometalate anion primarily dominated by the Coulombic attraction completely changed the dissociation chemistry of $\left[\mathrm{XM}_{12} \mathrm{O}_{40}\right]^{\mathrm{n}-}$. Instead of breaking the non-covalent bond or the multiple $\mathrm{M}-\mathrm{O}$ bonds on the framework of $\left[\mathrm{XM}_{12} \mathrm{O}_{40}\right]^{\mathrm{n}-}$, $\left\{\mathrm{TBA}\left[\mathrm{XM}_{12} \mathrm{O}_{40}\right]\right\}^{(\mathrm{n}-1)-}$ fragmented to give rise to its product ion $\left\{\left(\mathrm{C}_{4} \mathrm{H}_{9}\right)\left[\mathrm{XM}_{12} \mathrm{O}_{40}\right]\right\}^{(\mathrm{n}-1)-}$ by cleaving the $\mathrm{N}-\mathrm{C}$ covalent bond inside the $\mathrm{TBA}^{+}$cation (Figure 4). Note that the retainment of the Coulombic interaction in the product ion $\left\{\left(\mathrm{C}_{4} \mathrm{H}_{9}\right)\left[\mathrm{XM}_{12} \mathrm{O}_{40}\right]\right\}^{(\mathrm{n}-1)-}$ serves as an additional
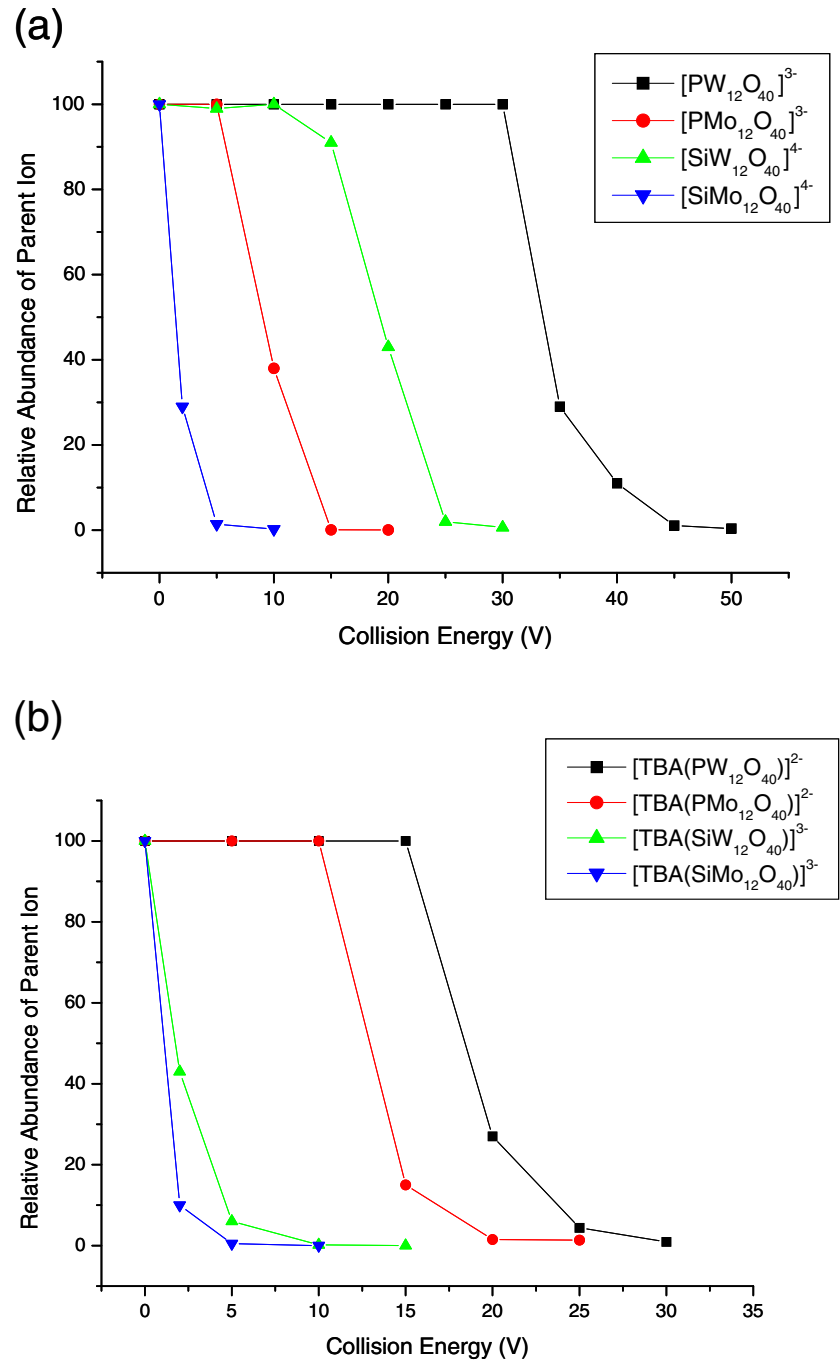

(c)

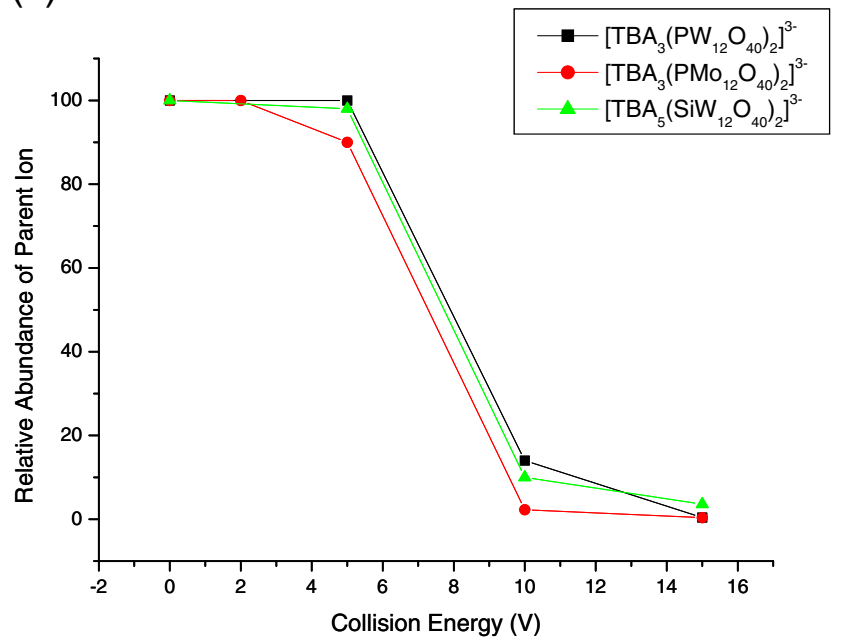

Figure 6. The dissociation curves for (a) $\left[\mathrm{XM}_{12} \mathrm{O}_{40}\right]^{\mathrm{n}-}$, (b) $\left\{\mathrm{TBA}\left[\mathrm{XM}_{12} \mathrm{O}_{40}\right]\right\}^{(\mathrm{n}-1)-}$, and (c) $\left\{\mathrm{TBA}_{\mathrm{m}}\left[\mathrm{XM}_{12} \mathrm{O}_{40}\right]_{2}\right\}^{3-}$ 
evidence for the strong non-covalent interaction between $\mathrm{TBA}^{+}$and $\left[\mathrm{XM}_{12} \mathrm{O}_{40}\right]^{\mathrm{n}-}$. Further decomposition of $\left\{\left(\mathrm{C}_{4} \mathrm{H}_{9}\right)\left[\mathrm{XM}_{12} \mathrm{O}_{40}\right]\right\}^{(\mathrm{n}-1)-}$ to form $\left[\mathrm{XM}_{12} \mathrm{O}_{40}\right]^{(\mathrm{n}-1)-}$ was also observed at higher collision energies as a result of the same type of fragmentation.

To this end, it is necessary to summarize the intriguing role of the $\mathrm{TBA}^{+}$cation in the dissociation chemistry of $\left\{\mathrm{TBA}\left[\mathrm{XM}_{12} \mathrm{O}_{40}\right]\right\}^{(\mathrm{n}-1)-}$ : It is not only the counter ion to balance the negative charge of POM clusters, but also as a part of the reaction substrate to participate the decomposition reaction of $\left\{\mathrm{TBA}\left[\mathrm{XM}_{12} \mathrm{O}_{40}\right]\right\}^{(\mathrm{n}-1)-}$.

In contrast to the complexity of $\left\{\mathrm{TBA}\left[\mathrm{XM}_{12} \mathrm{O}_{40}\right]\right\}^{(\mathrm{n}-1)-}$, the dimeric noncovalent complexes $\left\{\mathrm{TBA}_{\mathrm{m}}\left[\mathrm{XM}_{12} \mathrm{O}_{40}\right]_{2}\right\}^{3-}$ undergo simple dissociation by breaking the non-covalent bond between $\left[\mathrm{XM}_{12} \mathrm{O}_{40}\right]^{\mathrm{n}-}$ and $\mathrm{TBA}^{+}$leading to a pair of product ions comprising of a doubly charged $\left\{\mathrm{TBA}_{\mathrm{i}}\left[\mathrm{XM}_{12} \mathrm{O}_{40}\right]\right\}^{2-}$ and a singly charged $\left\{\mathrm{TBA}_{\mathrm{m}-\mathrm{i}}\left[\mathrm{XM}_{12} \mathrm{O}_{40}\right]\right\}^{-}$species (Equation 4, Figure 5).

$$
\left\{T B A_{m}\left[X M_{12} O_{40}\right]_{2}\right\}^{3-} \rightarrow\left\{T B A_{i}\left[X M_{12} O_{40}\right]\right\}^{2-}+\left\{T B A_{m-i}\left[X M_{12} O_{40}\right]\right\}^{-}
$$

( $\mathrm{m}$ and $\mathrm{i}=3$ and 1 or 5 and 2 )

The composition of $\left\{\mathrm{TBA}_{\mathrm{m}}\left[\mathrm{XM}_{12} \mathrm{O}_{40}\right]_{2}\right\}^{3-}$ was dependent on the charge state of the $\left[\mathrm{XM}_{12} \mathrm{O}_{40}\right]^{\text {n- }}$ core. The net charge was always kept at 3- no matter the stoichiometric

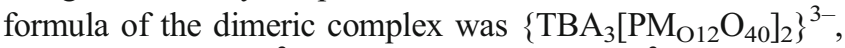

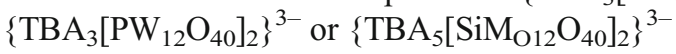

Relative Stabilities of $\left[\mathrm{XM}_{12} \mathrm{O}_{40}\right]^{n-}$, $\left\{\mathrm{TBA}\left[\mathrm{XM} M_{12} \mathrm{O}_{40}\right]\right\}^{(n-1)}$, and $\left\{\mathrm{TBA} \mathrm{A}_{m}\left[X M_{12} \mathrm{O}_{40}\right]_{2}\right\}^{3-}$ in the Gas Phase

It was suggested that the relative stabilities of ions with structural comparability can be evaluated from the relative dissociation energies under the same experimental conditions $[30,31]$. The relative dissociation energies, the $E_{1 / 2}$ values, defined as the point at which half of the isolated parent ion had dissociated, were determined from the plots of relative abundance of the parent ion versus applied collisional energy (Figure 6). It should be noted that we just use the $\mathrm{E}_{1 / 2}$ values as a semiquantitative basis to estimate the relative stability order of the relevant clusters.

It was concluded that the relative stabilities of the noncovalent complexes increase in the order $\left\{\mathrm{TBA}_{\mathrm{m}}\left[\mathrm{XM}_{12} \mathrm{O}_{40}\right]_{2}\right\}^{3-}<$ $\left\{\mathrm{TBA}\left[\mathrm{XM}_{12} \mathrm{O}_{40}\right]\right\}^{(\mathrm{n}-1)-}$. In other words, the bond strength of $\left\{\mathrm{TBA}_{\mathrm{m}}\left[\mathrm{XM}_{12} \mathrm{O}_{40}\right]_{2}\right\}^{3-}$ is much weaker than that of $\left\{\mathrm{TBA}\left[\mathrm{XM}_{12} \mathrm{O}_{40}\right]\right\}^{\left({ }^{(0)-1)-}\right.}$. This experimental observation confirmed with our previous findings deduced from the decomposition reaction of $\left\{\mathrm{TBA}\left[\mathrm{XM}_{12} \mathrm{O}_{40}\right]\right\}^{(\mathrm{n}-1)-}$. Indeed, the interaction between $\mathrm{TBA}^{+}$and $\left[\mathrm{XM}_{12} \mathrm{O}_{40}\right]^{\mathrm{n}-}$ was substantially lessened by sharing a few $\mathrm{TBA}^{+}$ cations with two $\left[\mathrm{XM}_{12} \mathrm{O}_{40}\right]^{\mathrm{n}-}$ anions. Moreover, it was also found that the relative stabilities of the bare $\left[\mathrm{XM}_{12} \mathrm{O}_{40}\right]^{\mathrm{n}-}$ anions are directly related to the charge state as well as the nature of $\mathrm{X}$ and $\mathrm{M}$ of POM clusters with the exception of the $\left\{\mathrm{TBA}_{\mathrm{m}}\left[\mathrm{XM}_{12} \mathrm{O}_{40}\right]_{2}\right\}^{3-}$ complexes, whose $\mathrm{E}_{1 / 2}$ values are in close proximity to each other, suggesting that the non-covalent bonds are extremely weak that they are leveled to a approximately uniform value in the complexes.

The relative stabilities of $\left[\mathrm{XM}_{12} \mathrm{O}_{40}\right]^{\mathrm{n}-}$ with regard to different $\mathrm{X}$ and $\mathrm{M}$ decrease in the order of $\left\{\mathrm{PW}_{12}\right\}>$ $\left\{\mathrm{SiW}_{12}\right\}>\left\{\mathrm{PMo}_{12}\right\}>\left\{\mathrm{SiMo}_{12}\right\}$. The bare tungstencontaining clusters are generally more stable than the molybdenum-containing clusters in the gas phase. This result is valuable because it is in excellent agreement with the relative orders of thermal stability in the condensed phase, obtained from measuring the thermal decomposition temperatures by TG-DTA [32]. It indicated a direct correlation between the condensed-phase and the gas-phase clusters. ESI-MS can thus be used to evaluate properties of the POM clusters in the condensed-phase.

The relative stabilities of $\left\{\mathrm{TBA}\left[\mathrm{XM}_{12} \mathrm{O}_{40}\right]\right\}^{(\mathrm{n}-1)-}$ complexes are partially different from those of bare polyoxoanions: $\left\{\mathrm{PW}_{12}\right\}>\left\{\mathrm{PMo}_{12}\right\}>\left\{\mathrm{SiW}_{12}\right\}>\left\{\mathrm{SiMo}_{12}\right\}$, which demonstrated that the dominant factor to determine the gas-phase stabilities of these complexes is their chemical composition, not only the net charge.

\section{Acknowledgments}

The authors acknowledge support for this work by university research grants provided by Beijing Institute of Technology (no. 20101742035).

\section{References}

1. Daniel, J.M., Friess, S.D., Rajagopalan, S., Wendt, S., Zenobi, R.: Quantitative determination of noncovalent binding interactions using soft ionization mass spectrometry. Int. J. Mass Spectrom. 216, 1-27 (2002)

2. Pope, M.T.: Heteropoly and Isopoly Oxometalates (Chapter 2, pp. 1532). Springer-Verlag, Berlin (1983)

3. Finke, R.G., Droege, M.W., Cook, J.C., Suslick, K.S.: Fast atom bombardment mass spectroscopy of polyoxoanions. J. Am. Chem. Soc. 106, 5750-5751 (1984)

4. Suslick, K.S., Cook, J.C., Rapko, B., Droege, M.W., Finke, R.G.: Characterization of very large polyoxoanions by fast atom bombardment mass spectroscopy (FABMS). Inorg. Chem. 25, 241-243 (1986)

5. Wasfi, S.H., Costello, C.E., Rheingold, A.L., Haggerty, B.S.: Preparation and characterization of two new isomorphous heteropoly oxofluorotungstate anions: $\left[\mathrm{CoW}_{17} \mathrm{O}_{56} \mathrm{~F}_{6} \mathrm{NaH} 4\right]^{9-}$ and $\left[\mathrm{FeW}_{17} \mathrm{O}_{56} \mathrm{~F}_{6} \mathrm{NaH}_{4}\right]^{8-}$. Inorg. Chem. 30, 1788-1792 (1991)

6. Abrams, M.J., Costello, C.E., Shaikh, S.N., Zubieta, J.: Keggin polyoxotungstate derivatives containing technetium. Inorg. Chim. Acta 180, 9-11 (1991)

7. Trovarelli, A., Finke, R.G.: Characterization of large, polyanionic inorganic molecules: Fast atom bombardment mass spectrometry of $\mathrm{P}_{2} \mathrm{~W}_{15} \mathrm{Nb}_{3} \mathrm{O}_{62}{ }^{9-}$ and of the supported organometallic catalyst precursor (1,5-COD) Ir. $\mathrm{P}_{2} \mathrm{~W}_{15} \mathrm{Nb}_{3} \mathrm{O}_{62}{ }^{8-}$. Inorg. Chem. 32, 6034-6039 (1993)

8. Colton, R., Traeger, J.C.: The application of electrospray mass spectrometry to ionic inorganic and organometallic systems. Inorg. Chim. Acta 201, 153-155 (1992)

9. Deery, M.J., Howarth, O.W., Jennings, K.R. Application of electrospray ionisation mass spectrometry to the study of dilute aqueous oligomeric anions and their reactions. J. Chem. Soc., Dalton Trans. 4783-4788 (1997)

10. Truebenbach, C.S., Houalla, M., Hercules, D.M.: Characterization of isopoly metal oxyanions using electrospray time-of-flight mass spectrometry. J. Mass Spectrom. 35, 1121-1127 (2000) 
11. Sahureka, F., Burns, R.C., Nagy-Felsobuki, E.I.: Electrospray ionization mass spectroscopic characterisation of isopolyoxo-niobates and tantalates. Inorg. Chim. Acta 351, 69-78 (2003)

12. Nellutla, S., van Tol, J., Dalal, N.S., Bi, L.H., Kortz, U., Keita, B., Nadjo, L., Khitrov, G.A., Marshall, A.G.: Magnetism, electron paramagnetic resonance, electrochemistry, and mass spectrometry of the pentacopper(II)substituted tungstosilicate $\left[\mathrm{Cu}_{5}(\mathrm{OH})_{4}\left(\mathrm{H}_{2} \mathrm{O}\right)_{2}\left(\mathrm{~A}-\alpha-\mathrm{SiW}_{9} \mathrm{O}_{33}\right)_{2}\right]^{10-}$, a model five-spin frustrated cluster. Inorg. Chem. 44, 9795-9806 (2005)

13. Pradeep, C.P., Long, D.L., Kögerler, P., Cronin, L. Controlled assembly and solution observation of a $2.6 \mathrm{~nm}$ polyoxometalate 'super' tetrahedron cluster: $\left[\mathrm{KFe}_{12}(\mathrm{OH})_{18}\left(\alpha-1,2,3-\mathrm{P}_{2} \mathrm{~W}_{15} \mathrm{O}_{56}\right)_{4}\right]^{29-}$. Chem. Commun. 4254-4256 (2007)

14. Long, D.L., Streb, C., Song, Y.F., Mitchell, S., Cronin, L.: Unraveling the complexities of polyoxometalates in solution using mass spectrometry: Protonation versus heteroatom inclusion. J. Am. Chem. Soc. 130, 18301832 (2008)

15. Fay, N., Bond, A.M., Baffert, C., Boas, J.F., Pilbrow, J.R., Long, D.L., Cronin, L.: Structural, electrochemical, and spectroscopic characterization of a redox pair of sulfite-based polyoxotungstates: $\alpha-\left[\mathrm{W}_{18} \mathrm{O}_{54}\left(\mathrm{SO}_{3}\right)_{2}\right]^{4}$ and $\alpha-\left[\mathrm{W}_{18} \mathrm{O}_{54}\left(\mathrm{SO}_{3}\right)_{2}\right]^{5-}$. Inorg. Chem. 46, 3502-3510 (2007)

16. Pradeep, C.P., Long, D.L., Newton, G.N., Song, Y.F., Cronin, L.: Supramolecular metal oxides: Programmed hierarchical assembly of a protein-sized $21 \mathrm{kDa}\left[\left(\mathrm{C}_{16} \mathrm{H}_{36} \mathrm{~N}\right)_{19}\left\{\mathrm{H}_{2} \mathrm{NC}\left(\mathrm{CH}_{2} \mathrm{O}\right)_{3} \mathrm{P}_{2} \mathrm{~V}_{3} \mathrm{~W}_{15} \mathrm{O}_{59}\right\}_{4}\right]^{5-}$ polyoxometalate assembly. Angew. Chem. Int. Ed. 47, 4388-4391 (2008)

17. Long, D.L., Song, Y.F., Wilson, E.F., Kögerler, P., Guo, S.X., Bond, A M., Hargreaves, J.S.J., Cronin, L.: Capture of periodate in a W18O54 cluster cage yielding a catalytically active polyoxometalate [H3W18O56(IO6)]6- embedded with high-valent iodine. Angew. Chem. Int. Ed. 47, 4384-4387 (2008)

18. Xu, F., Scullion, R.A., Yan, J., Miras, H.N., Busche, C., Scandurra, A., Pignataro, B., Long, D.L., Cronin, L.: A Supramolecular heteropolyoxopalladate Pd15 cluster host encapsulating a $\mathrm{Pd} 2$ dinuclear guest: $[$ PdII $\subset\{$ H7PdII15O10(PO4)10 $\}] 9-$. J. Am. Chem. Soc. 133, 46844686 (2011)

19. Yan, J., Gao, J., Long, D.L., Miras, H.N., Cronin, L.: Self-assembly of a nanosized, saddle-shaped, solution-stable polyoxometalate anion built from pentagonal building blocks: $\left[\mathrm{H}_{34} \mathrm{~W}_{119} \mathrm{Se}_{8} \mathrm{Fe}_{2} \mathrm{O}_{420}\right]^{54-}$. J. Am. Chem. Soc. 132, 11410-11411 (2010)

20. Lau, T.C., Wang, J., Guevremont, R., Siu, K.W.M. Electrospray tandem mass spectrometry of polyoxoanions. J. Chem. Soc. Chem. Commun. 877-878 (1995)
21. Ma, M.T., Waters, T., Beyer, K., Palamarczuk, R., Richardt, P.J.S., O'Hair, R.A.J., Wedd, A.G.: Gas-phase fragmentation of polyoxotungstate anions. Inorg. Chem. 48, 598-606 (2009)

22. Bray, T.H., Copping, R., Shuh, D.K., Gibson, J.K.: Electrospray ionization mass spectrometry of a cerium(III) phosphomolybdate complex: Condensed and gas-phase cluster chemistry. Int. J. Mass Spectrom. 299, 35-46 (2011)

23. Cao, G.J., Lin, J., Fang, W.H., Zheng, S.T., Yang, G.Y.: Openframework aluminoborates co-templated by two types of primary amines. Dalton Trans. 40, 2940-2946 (2011)

24. Pradeep, C.P., Long, D.L., Cronin, L.: Cations in control: Crystal engineering polyoxometalate clusters using cation directed self-assembly. Dalton Trans. 39, 9443-9457 (2010)

25. Yan, J., Long, D.L., Miras, H.N., Cronin, L.: Cation controlled assembly and transformation of mono- and bi-sulfite templated Dawson-type polyoxotungstates. Inorg. Chem. 49, 1819-1825 (2010)

26. Yamase, T., Ishikawa, E., Asai, Y., Kanai, S.: Alkene epoxidation by hydrogen peroxide in the presence of titanium-substituted Keggin-type polyoxotungstates $\left[\mathrm{PTixW}_{12-\mathrm{x}} \mathrm{O}_{40}\right]^{(3+2 \mathrm{X})-}$ and $\left[\mathrm{PTi}_{\mathrm{x}} \mathrm{W}_{12-\mathrm{x}} \mathrm{O}_{40-\mathrm{x}}\left(\mathrm{O}_{2}\right)_{\mathrm{x}}\right]^{(3+2 \mathrm{x})-}$ ( $\mathrm{x}=1$ and 2). J. of Mol. Catal. A Chem. 114, 237-245 (1996)

27. Kholdeeva, O.A., Trubitsina, T.A., Timofeeva, M.N., Maksimov, G.M., Maksimovskaya, R.I., Rogov, V.: The role of protons in cyclohexene oxidation with $\mathrm{H}_{2} \mathrm{O}_{2}$ catalysed by Ti(IV)-monosubstituted Keggin polyoxometalate. J. Mol. Catal. A Chem. 232, 173-178 (2005)

28. Li, C., Gao, J., Jiang, Z., Wang, S., Lu, H., Yang, Y., Jing, F.: Selective oxidations on recoverable catalysts assembled in emulsions. Top. Catal. 35, 169-175 (2005)

29. Ross, A.R.S., Ikonomou, M.G., Thompson, J.A.J., Orians, K.J.: Anal. Chem. 70, 2225-2235 (1998)

30. Penn, S.G., He, F., Green, M.K., Lebrilla, C.B.: The use of heated capillary dissociation and collision-induced dissociation to determine the strength of non-covalent bonding interactions in gas-phase peptide-cyclodextrin complex. J. Am. Soc. Mass Spectrom. 8, 244252 (1997)

31. David, W.M., Brodbelt, J.S.: Threshold dissociation energies of protonated amine/polyether complexes in a quadrupole ion trap. $J$. Am. Soc. Mass Spectrom. 14, 383-392 (2003)

32. Kong, A.G., Zhang, S.M., Zhang, D.W., Lü, L.L., Jin, C., Shan, Y. K.: Thermal decomposition behavior of metal-oxygen clusters with Keggin structure. Chem. J. Chinese Universities 26, 2002-2006 (2005) 